\title{
Effect of vegetative propagation on field performance up to age 8 of hybrid larch (Larix $x$ eurolepis) clones
}

\author{
LE Pâques, D Cornu \\ INRA, Station d'amélioration des arbres forestiers, centre de recherche d'Orléans, \\ F-45160 Ardon, France
}

(Received 15 November 1990; accepted 15 March 1991)

\begin{abstract}
Summary - More than 100 clones of hybrid larch (Larix $\mathrm{x}$ eurolepis) have been vegetatively propagated by stem cuttings and their behaviour under field conditions been examined in 2 clonal tests up to age 8 and $10 \mathrm{yr}$. Rooting rate was high $(87 \%)$ but very variable from clone to clone. Transfer of rooted cuttings from greenhouse to the nursery remained a serious problem. No correlation between ortet vigour (total height at age $2 \mathrm{yr}$ ) and rooting ability could be found. Rooted cuttings behaved mostly like seedlings for both growth traits and stem form, at least when taken from young ortets (2 $\mathrm{yr}$ old). Age (2 compared to $16 \mathrm{yr}$ ) of donor plants seemed to have long-lasting effects (up to age 10 $y r$ ) on further growth of ramets. The genetic composition evolution of a fictive multiclonal variety was simulated up to age $8 \mathrm{yr}$. No major change in the representation of the component clones could be observed.
\end{abstract}

Larix $\mathrm{x}$ eurolepis / vegetative propagation / stem cutting / clonal test / hybrid larch

Résumé - Comportement en forêt à 8 ans de clones de mélèze hybride (Larix $x$ eurolepis) multipliés par voie végétative. Une centaine de clones (expérience 1) et 21 autres clones (expérience 2) de mélèze hybride ont été multipliés végétativement par bouturage horticole et installés à Eclache (Puy-de-Dôme) et à Peyrat-Le-Château (Haute-Vienne). Le comportement des clones en forêt à 8 ans (et 10 ans pour l'expérience 2) a été étudié de manière à vérifier l'intérêt de la voie clonale, et en particulier le bien-fondé de certaines critiques formulées à l'encontre de la multiplication végétative. II ressort de cette étude que :

- le taux d'enracinement global est élevé (87\%) mais varie notablement de clone à clone (37$100 \%)$. L'acclimatation des boutures enracinées en pépinière reste une opération délicate qui se traduit par des pertes en matériel importantes $( \pm 50 \%)$ liêes à un système racinaire insuffisant et à des conditions de repiquage sur le terrain trop sévères;

- il ne semble pas y avoir de liaison entre la vigueur de l'ortet (sa taille) et son aptitude à l'enracinement;

- le niveau de croissance des plants bouturés installés en forêt est très semblable à celui observé pour les plants issus de semis et la qualité de la forme des tiges est comparable, du moins lorsque le bouturage se fait à partir de pieds mères jeunes (2 ans);

- l'âge des pieds mères semble avoir un effet durable sur la croissance ultérieure des ramets qui en sont issus. $\dot{A} 10$ ans, les ramets issus de pieds mères jeunes (2 ans depuis la graine) conservent un avantage pour la croissance très net par rapport aux ramets tirés de pieds mères âgés (16 ans);

- parmi les soucis majeurs posés par la multiplication en masse d'une variété clonale, une dérive immédiate (lors du bouturage) mais aussi progressive (au cours de la vie du peuplement)-de sa composition génétique limiterait la diversité génétique initiale recherchée avec les risques que cela comporte. Une simulation de l'évolution au cours du temps (jusqu'à 8 ans) de la représentativité de 
chaque clone dans la variété clonale montre que dans le cadre de cette étude, les risques de dérive sont mineurs et acceptables.

L'étude de l'intérêt économique de la voie végétative par rapport à la voie sexuée n'a pas été abordée dans cet article. Le niveau des gains génétiques attendus sera étudié par ailleurs.

Larix x eurolepis / multiplication végétative / bouturage / test clonal / mélèze hybride

\section{INTRODUCTION}

The hybrid between the European (Larix decidua Mill) and Japanese larches (Larix kaempferi (Sarg) Carr) has proved to be a valuable reforestation material in many experiments (Bastien and Keller, 1980; Gothe, 1987). Its superiority over one or both of its parental species has been illustrated for many important traits such as vigour, form and canker resistance (Pâques, 1989).

Once a hybrid formula (usually a full-sib family) is selected for its outstanding performances, questions about its mass propagation arise. In order to take advantage of both additive and dominance genetic effects, 2 propagation systems are available to tree breeders, namely bi-clonal hybridization seed orchards and vegetative propagation by cuttings.

Propagation through sexual reproduction in hybridization orchards appears in many ways problematic for biological constraints such as non-overlapping phenology between the clones of the different species, for genetic limits (eg purity level of hybrid seed, narrow genetic base of biclonal orchard progeny), for economic reasons (cost of investment and delay in returns) and connected with this, reduced flexibility for mass-propagation of new varieties.

Vegetative propagation is in this respect much more flexible and suited to a rapid diffusion of new improved varieties. Stem cutting techniques are available for larches
(Mason, 1984; Morgenstern, 1987; Jacques and Nanson, 1989) among which propagation of selected individuals (ortets) managed in hedged clone archives and, alternatively, "bulk" propagation of young forced seedlings of entire selected families are of interest.

Validity of both techniques is guaranteed by a high rate of multiplication per donor plant (ie number of cuttings which can be taken per tree $x$ level of rooting success), by a stable and balanced representation of each clone in the clonal variety, a physiological quality of clonal material at least equivalent to similar genetic seedling material, and the genetic quality of the propagated clones.

Propagation of multiclonal varieties from selected donor plants (ortets) faces 2 additional major problems: efficiency of selection and management of ageing in the donor plant collections.

The objective of this paper was to determine the feasibility and the value of stem cutting propagation in selected hybrid larch clones. The following points have been examined: i), clonal variation of rooting ability; ii), influence of ortet vigour on rooting ability; iii), evolution of the genetic composition of a fictive multiclonal variety; and iv), forest behaviour of cloned material, in particular with respect to the age effect of donor plants and in comparison to seedlings.

A second paper will study basic genetic parameters of vegetatively propagated material in order to determine the level of ge- 
netic gains to be expected through clonal selection.

\section{MATERIALS AND METHODS}

\section{Observations and results derived from 2 different experiments}

\section{Experiment 1}

101 clones of Larix $x$ eurolepis (European $x$ Japanese larches) (coded Ldk C) were selected in a progeny test at age $2 \mathrm{yr}$ among 14 full-sib families created in 1979 at the INRA Research Station, Orléans. Ortets were potted in autumn 1981 and forced under greenhouse conditions a couple of weeks before propagation.

Softwood cuttings ( $\approx 10 \mathrm{~cm}$ long) were taken in May 1982, dipped in talc powder including $0.5 \%$ IBA and a fungicide, and rooted in a medium mixture (2:1:3) of peat, compost and pouzzolane under greenhouse conditions. An intermittent mist was used and alternating fungicide treatments were applied as necessary. Rooted cuttings were transferred to INRA nursery in March 1983, 2 yr before being field-planted.

Rooted material was planted on one test site in the Eclache state forest in December 1984. The site is located in the Massif Central (Puyde-Dôme, long $2^{\circ} 41^{\prime} \mathrm{E}$, lat $45^{\circ} 44^{\prime} \mathrm{N}$, elev $1000 \mathrm{~m}$ ) and can be regarded as a good conifer forest site (deep forest brown soil, high level of annual rainfall (up to $1000 \mathrm{~mm}$ )), except for the windy conditions.

An incomplete balanced random blocks design was used with 9 blocks, 95 plants per block and 2 non-contiguous tree plots per clone and per block. Spacing was $3 \times 3 \mathrm{~m}$ wide.

Seedlings of 2 full-sib families of Larix $\times$ Eurolepis (coded Ldk S) were included, one of them being represented both by seedlings (F0001 S) and by 10 clones (F0001 C). Other seedilings (coded Lkd S) and 25 clones (coded Lkd C) selected at age 3 yr from a Danish seed orchard (FP203 $=$ F0025) progeny were added as well. This orchard produces the reciprocal hybrid Larix $x$ leptoeuropaea (Japanese $\times$ Europe- an larches). Sowing took place in the same nursery but 1 yr later than vegetative propagation.

Experiment 1 was the first large-scale experiment conducted at the INRA Research Station on vegetative propagation of hybrid larch.

\section{Experiment 2}

Experiment 2 consisted of a small clonal test including 21 clones of Larix $x$ eurolepis selected from the progeny of another Danish hybridization seed orchard (FP201). The age effect of donor stock on further development of cuttings was studied. Seven clones were chosen for stem straightness in a provenance test (CoatAn-Noz, Brittany) in 1973 at age $16 \mathrm{yr}$ (from seed) and grafted on potted rootstocks at the INRA Orléans nursery (old material). Fourteen other clones were selected for the same criteria among 2-yr-old seedlings by year of vegetative propagation (young material).

In spring 1978, the 21 clones were vegetatively propagated by stem cuttings and planted at one site in Peyrat-Le-Château (Haute-Vienne, long $1^{\circ} 44^{\prime} \mathrm{E}$; lat $45^{\circ} 49^{\prime} \mathrm{N}$; elev $450 \mathrm{~m}$; western range of the Massif Central) in spring 1981.

The experimental design was a complete random block design with 8 blocks and single tree plots. Spacing was $3 \times 2 \mathrm{~m}$.

\section{Measurements and observations}

Besides total height of ortets measured in 1981 at age $2 \mathrm{yr}$ (from seed, coded H81/2), nursery measurements included: the rate of rooting success (\%RC82), the quality of the root system assessed by a notation scale with 4 scores $(1=$ numerous roots well distributed around the stem base; $2=$ intermediate; 3 = poor root system with 1 or 2 roots and a unilateral distribution; $4=$ no root) and the percentage of plantable cuttings prior to planting (\%PC84). The latter was based on the proportion of viable cuttings with a good root system quality (score 1 or 2 ).

Forest observations were made in 1989 for experiment 1 ( $8 \mathrm{yr}$ after propagation) and in 1987 (10 yr after propagation) for experiment 2. They concerned survival rate (\%S), total height 
$(\mathrm{H})$, the length of the cumulated shoot growth increments from plantation $(\mathrm{Cl})$, girth at breast height (BHG) (only in experiment 2), frequency of basal sweep (\%BS), stem straightness (SS) a notation with 5 scores was used $(1=$ very poor, 5 = straight stem) - and frequency of crooked stems (scores $<4$ in the previous scale) (\%CS). Branch angle and forking were observed in experiment 2 but as no variation was observed, they were discarded before analysis.

\section{Analysis of data}

\section{Experiment 1}

Statistical methods used were Spearman rank correlations between ortet performances and rooting traits of clones and comparison of means by Student-Fisher $t$-test for comparison of seedling-cutting performances (Dagnelie, 1975). Homogeneity of frequency data was tested using test I (Arbonnier, 1966) with:

$I=\Sigma_{i j} X_{i j} \log X_{i j}+N \log N-\Sigma_{i} X_{i .} \log X_{i}-\Sigma_{j} X_{. j}$
$\log X_{. j}$

with $X_{i j}=$ number of observations of type $i$ and score $j ; X_{i}, X_{j}=$ marginal sum of observations; $n=$ number of scores; $k=$ number of types; $N=$ total number of observations.

It follows a $\chi^{2}$ distribution with $(k-1)(n-1)$ degrees of freedom.

\section{Experiment 2}

Age of donor plants and clone (within-age) effects were tested following an analysis of variance on individual data according to the model:

$$
Y_{i j k l}=\mu+B_{i}+A_{j}+C / A_{k(j)}+\varepsilon_{i j k l}
$$

with $\mu=$ general mean; $B_{i}=$ effect of block $i ; A_{j}=$ effect of donor plant age $j ; C / A_{k(j)}=$ effect of clone $k$ of donor plant of age $j ; \varepsilon_{i j k l}=$ residual error.

Main factors were considered as random.

Test I (Arbonnier, 1966) was used to test homogeneity of response for frequency data.

\section{RESULTS AND DISCUSSION}

\section{Rooting ability and quality (exp 1)}

Average values of rooting characteristics are given in table I for hybrids Ldk $\mathrm{C}$ and Lkd C.

Rooting rate was particularly high for Ldk $C$ as well as its general root system quality: out of 2748 cuttings, $87 \%$ were rooted and $88 \%$ of rooted cuttings had a good root system. Hybrid Lkd $\mathrm{C}$, on the other hand, was much less successful if one considers the rate of rooting $(64 \%)$, the number of remaining clones before plantation and especially the rate of plantable cuttings: $14.1 \%$. This parameter, which takes into account rooting success percentage, root system quality and survival in the nursery until forest plantation was not very high for Ldk $C$ either, as just 1 cutting out of 2 taken in 1982 from donor plants could be finally planted in 1984 .

The poor results noted for hybrid Lkd $C$ clones might be explained by the fact that Lkd donor plants are $1 \mathrm{yr}$ older than Ldk plants. Mason (1984) recommended that stock plants $>2 \mathrm{yr}$ from seed should not be used.

Rooting rates observed in this study for Larix $\mathrm{x}$ eurolepis were somewhat weaker than comparable results reported in the literature. For cuttings collected and inserted in early May, Mason (1989) obtained overall rooting percentages as high as $95 \%$. Numerous factors might explain this difference in success: history of stock plants, developmental stage of the twigs at time of collection, rooting environment and clone variability in rootability.

Indeed, a high variability of the rooting response existed both between families and between clones; the rooting rates amplitude had a range of $76.0-94.0 \%$ between families and $37-100 \%$ between 


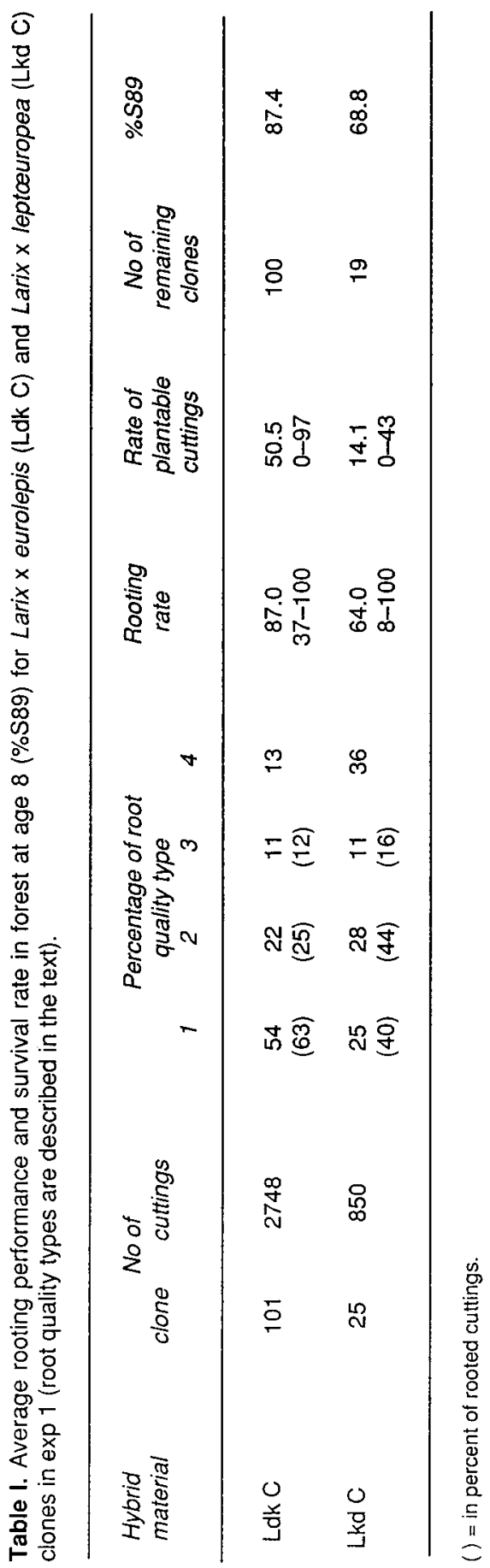


clones for Ldk $\mathrm{C}$, while percentages of plantable cuttings varied from $20.8-64.4 \%$ between families and from $0-97 \%$ between clones. Test I was significant for the 3 characteristics (rooting rate, root system quality and rate of plantable cuttings) revealing non-homogeneity of the rooting response of clones at the family level. Variation between ramets also existed and may be important for part of the clone 1 for traits such as root system quality.

Nevertheless, as shown in fig 1a, b, c, the frequency of clones with a rooting rate of at least $70 \%$ and an equivalent proportion of good rooted cuttings (types 1 and 2) was high as it reached more or less $80 \%$ but before plantation, nearly $50 \%$ of the clones had $<50 \%$ of plantable ramets, indicating serious problems connected with transfer from greenhouse to nursery.

\section{Influence of ortet vigour on rooting ability (experiment 1)}

Rank correlations between rooting characteristics and between these traits and total height of ortets at age $2 \mathrm{yr}$ in the nursery were computed. Positive, highly significant ( $\alpha=0.001$ ) correlations existed between rooting characteristics (table 11 ), though these were not very high. No correlation (significantly different from 0 at $\alpha=0.05$ ) could nevertheless be found between rooting traits and ortet vigour (H81/2).

Truncation of the initial population through selection might affect a generalization of this conclusion. But even in the families where selection intensity had been the weakest $(P=35 \%)$, vigour of ortets was not correlated with rooting response traits.
1 a

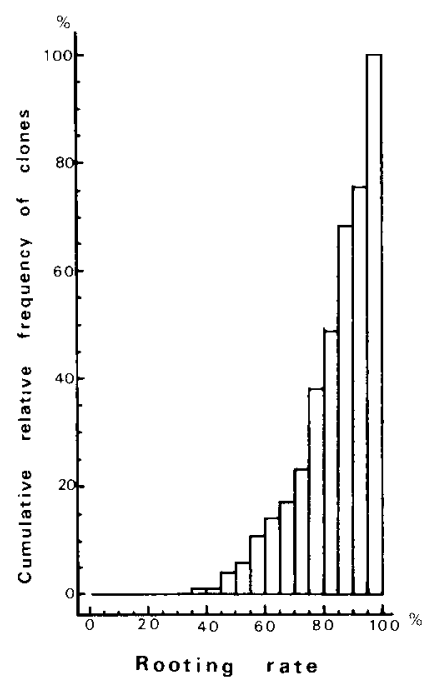

$1 \mathrm{~b}$

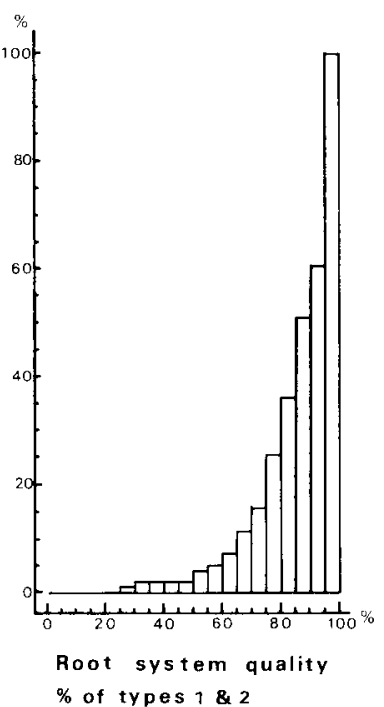

$1 \mathrm{c}$

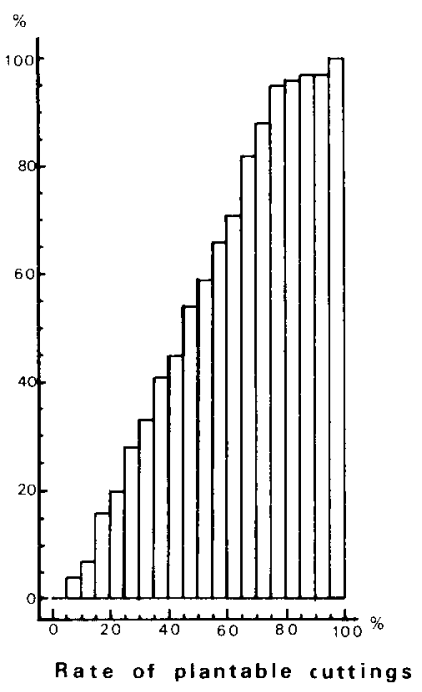

Fig 1. Distribution of clones (in cumulative relative frequency) for rooting success rate (1a), frequency of root system quality of types 1 and $2(1 \mathrm{~b})$ and proportion of plantable cuttings (1c). 
Table II. Spearman rank correlations between ortets vigour at age $2 \mathrm{yr}(\mathrm{H} 81 / 2)$ and rooting characteristics (exp 1).

\begin{tabular}{|c|c|c|c|c|}
\hline$r_{s}$ & $H 81 / 2$ & $\% R C .82$ & $\% P C .84$ & $\% C R T 1$ \\
\hline $\mathrm{H} 81 / 2$ & 1.000 & 0.72 NS & -0.041 NS & 0.033 NS \\
\hline $\begin{array}{l}\text { \%RC. } 82 \\
\text { \%PC. } 84 \\
\% C R T 1\end{array}$ & & 1.000 & $\begin{array}{l}0.563^{* * *} \\
1.000\end{array}$ & $\begin{array}{l}0.488^{\star \star \star} \\
0.701^{\star \star \star} \\
1.000\end{array}$ \\
\hline
\end{tabular}

NS = non significant at $\alpha=0.05 ;{ }^{* * *}$ significant at $\alpha=0.001 . \%$ RC. $82=$ rooting success rate; \%PC. $84=$ proportion of plantable cuttings; \%CRT 1 = percentage of rooted cuttings with type 1 root system quality.

\section{Genetic changes in composition of multiclonal varieties: a study case (experiment 1)}

Equal representation of clones in the final composition of a multiclonal variety is a guarantee of protection of its genetic diversity. Several factors ensure equal representation of clones. They concern donor plant reactions in terms of vigour and thus of number of cuttings which can be taken and the rapidity with which they become mature; they also concern clone rooting ability and their aptitude to survive both under nursery and forest plantation conditions.

Taking into account rooting parameters in experiment 1 , namely rooting percentage, quality of the root system and survival in nursery as well as in the forest up to age $8 \mathrm{yr}$, a simulation was attempted in order to determine a possible drift in the initial composition of a fictive multiclonal variety.

Twenty clones selected (out of 100 clones) on the basis of an index combining vigour and stem straightness at age $8 \mathrm{yr}$ (Pâques, unpublished observations) were chosen with the assumption that the same initial number of cuttings per clone was taken so that each clone had an equal rel- ative representation in the fictive multiclonal variety (ie $5 \%$ ) prior to rooting.

Evolution of the relative loss or gain of representation is presented in figure 2 at 3 stages: after rooting ( $y r \quad 1)$, at plantation time ( $\mathrm{yr} \mathrm{3}$ ) and in the forest ( $\mathrm{yr} 8$ ). It is interesting to note that the discrepancy from the initial representation is limited to a loss or gain of -3 to $+3.5 \%$ at maximum and concerns a minority of clones. Compensation between rooting ability, nursery transfer adaptability and survival in forest seems to exist and to be able to maintain a rather stable representation of clones.

Several other simulations have been tested including various numbers of selected clones (minimum 20) or considering family level of clones. Similar results were observed and are even more encouraging. As in the present case, genetic diversity and its clonal equal relative representation are ensured.

Nevertheless, this does not mean that because of between clones ageing variability or for purely genetic reasons -some clones respond very poorly to vegetative propagation- selection for rooting ability should not have to be considered as a specific selection criteria, at least as far as this trait is not negatively correlated with other traits of interest. 


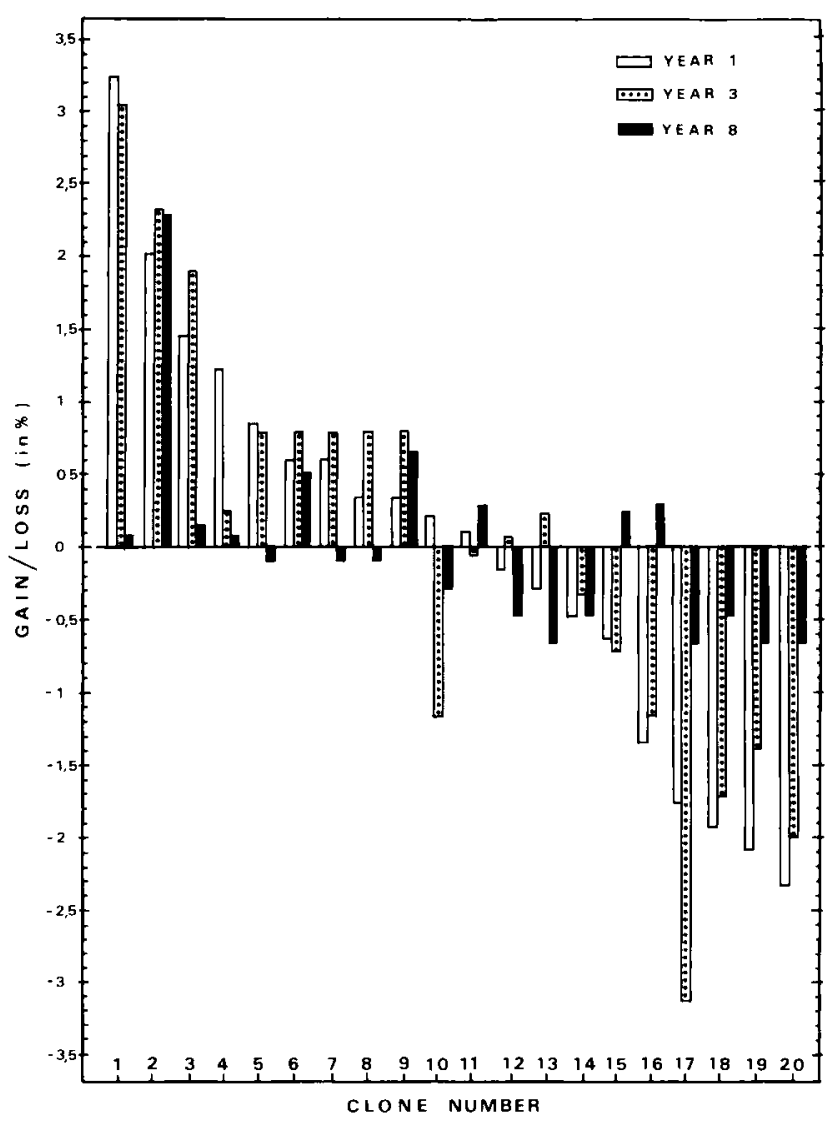

Fig 2. Evolution of clones representation in a fictive multiclonal variety after rooting (yr 1), before plantation ( $y r 3$ ) and at age 8 in forest ( $y r$ B) (expressed as the gain or loss in the relative contribution of the clone ramets in the variety over their initial representation).

\section{Behaviour of clonally propagated material in the forest}

\section{Age effect of the donor plant (experiment 2)}

Comparison of performances at age $10 \mathrm{yr}$ (from propagation) have been presented in table III for cuttings taken from young (2yr-old) and old (16-yr-old) donor plants se- lected in the same seed orchard progeny. Besides means and coefficients of variation, tests results (namely $F$-test and 1 -test) have also been given.

Vigour (total height and girth at age 10 yr) was particularly high for both materials and one of the strongest recorded in France for Larix $x$ eurolepis. Nevertheless, significant differences (at $\alpha=0.05$ ) existed between performance material in the 2 age 
Table III. Comparison of performances (means and coefficients of variation) at age 10 for cuttings taken from young and old donor plants. (exp 2).

\begin{tabular}{|c|c|c|c|c|c|}
\hline \multirow[b]{2}{*}{ Traits } & \multicolumn{4}{|c|}{ Age of donor plants } & \multirow[b]{2}{*}{$\begin{array}{l}\text { Comparison of } \\
\text { means }\end{array}$} \\
\hline & $\bar{x}^{Y_{c}}$ & $C V$ & $\bar{x}$ & $C V$ & \\
\hline $\begin{array}{l}\mathrm{H} 87 / 10 \quad(\mathrm{~cm}) \\
\mathrm{Cl} 81-87 \quad(\mathrm{~cm}) \\
\mathrm{BHG} 87 / 10(\mathrm{~cm})\end{array}$ & $\begin{array}{r}796.4 \\
701.3 \\
38.5\end{array}$ & $\begin{array}{r}9.3 \\
9.1 \\
15.1\end{array}$ & $\begin{array}{r}714.7 \\
650.9 \\
28.2\end{array}$ & $\begin{array}{l}13.0 \\
12.4 \\
24.4\end{array}$ & $\begin{array}{l}F 1,19=9.20^{* *} \\
F 1,19=5.50^{*} \\
F 1,19=33.24^{* * *}\end{array}$ \\
\hline $\begin{array}{l}\% B S 87 / 10 \\
\% \text { FO } 87 / 10 \\
\text { SS87/10 } \\
\% C S 87 / 10\end{array}$ & $\begin{array}{c}62.2 \\
9.0 \\
3.81 \\
31.5\end{array}$ & $\begin{array}{c}- \\
- \\
23.1 \\
-\end{array}$ & $\begin{array}{c}70.6 \\
5.9 \\
3.79 \\
32.4\end{array}$ & $\begin{array}{c}- \\
- \\
25.8 \\
-\end{array}$ & $\begin{array}{l}10,95=0.821 \mathrm{NS} \\
10,95=0.360 \mathrm{NS} \\
\mathrm{F} 1,19=0.00 \mathrm{NS} \\
10,95=0.008 \mathrm{NS}\end{array}$ \\
\hline
\end{tabular}

NS $=$ non-significantly different at $\alpha=0.05 ;{ }^{*},{ }^{* *},{ }^{* *}=$ significantly different at respectively $\alpha=0.05,0.01,0.001$; H87/10 = total height; $C \mid 81-87=$ cumulated ienght of mean height annual increment; $B H G=$ breast height girth; $\% B S 87 / 10=$ frequency of basal sweep; $\% F O 87 / 10=$ percentage of forked stems; $S S 87 / 10=$ stem straightness; $\% \mathrm{CS} 87 / 10=$ percentage of crooked stems.

classes. On average, young material clones were superior to old ones by $>11.0 \%$ and $7.7 \%$ respectively for $\mathrm{H} 87 / 10$ and $\mathrm{Cl} 81-87$, but the most spectacular difference occurred in favour of young material for breast height girth (up to $36.5 \%$ ).

This result is somewhat in opposition to the findings of Morgenstern (1987), who studied the age effect of parent plant on rooting for Larix laricina. Age effect was strong on rooting but though differences between age classes (3-4 to 9-10) persisted to the 5th year on height growth of cuttings, they became insignificant. Among possible explanations, it is worth noting that the latter study compared age effects with clones of different genetic origins and that the older age class was $\approx 6$ yr younger than in our study. In both studies, ' $C$ ' effects (defined by Burdon and Shelbourne (1974) as 'maternal' effect common to all ramets of a clone) due to different environments of parent plants were supposed to be negligible.

Clone within age of donor plant effects were also highly significant (for $\alpha=0.001$ ) (table IV). Except for one clone, all the other clones from old material had below average performances but 2 clones from young material also performed very poorly.

Regarding stem form, no significant differences between age of donor plants (for $\alpha=0.05$ ) seemed to exist at that age while clone within age effects were highly significant $(\alpha=0.001)$ for $S S 87 / 10$ (table IV).

Considering main source factors as random, variance components were estimated and have been presented in table IV as percentages of total variance. Except for SS87/10, expected variance for age of donor plants constituted a major part of the total variance and was even superior to clone/age variance but for most traits, the error term absorbed the largest part of the total variance.

\section{Comparison of seedlings and rooted cuttings (experiment 1 )}

Two-yr-old seedlings (S) and 3-yr-old rooted cuttings (C) from 2 families, 1 full-sib 


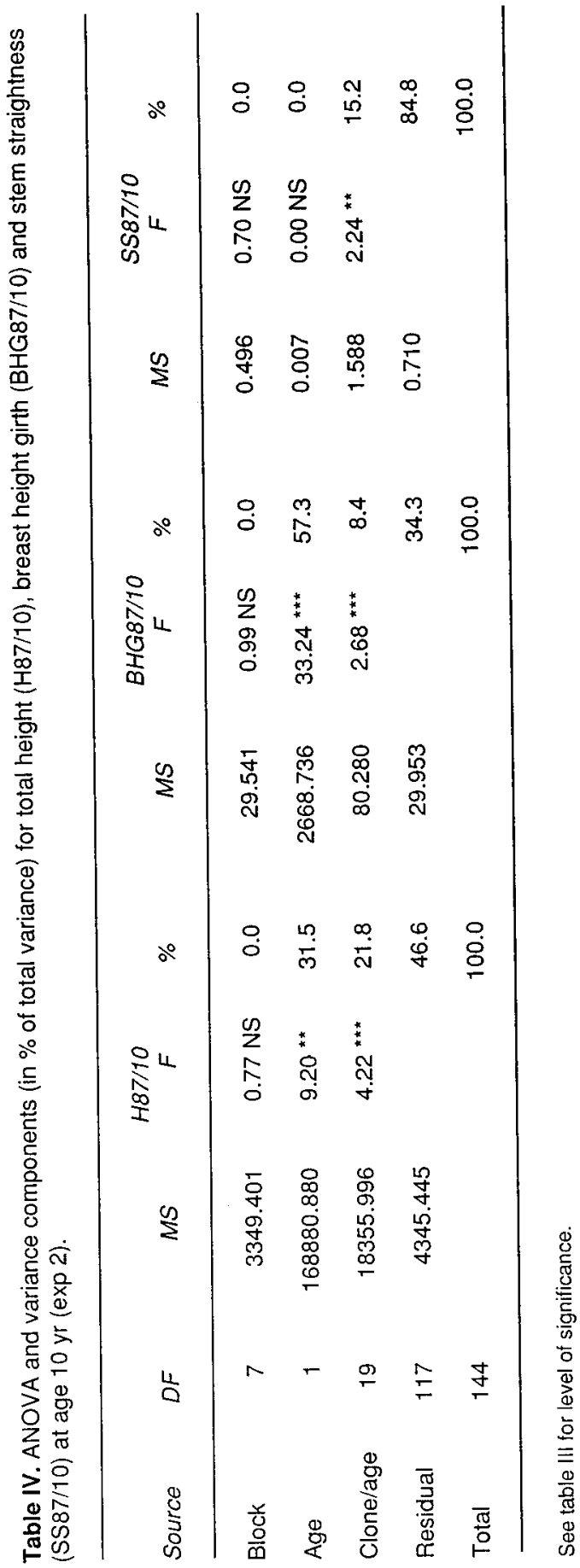


family of Larix $x$ eurolepis: F0001 and 1 seed orchard progeny of Larix $x$ leptoeuropaea: F0025, were compared under forest conditions in exp 1 for survival, vigour and stem form traits up to 1989 . Unfortunately, seedlings from both families were represented by a rather low number of individuals.

Mean performances and variability have been presented in table V. Tests of comparison of means (or frequencies) (tests $t$ and $I$ showed that seedlings and cuttings of both families were highly comparable for most traits. Exceptions existed, however, for family F0025; seedlings were significantly $(\alpha=0.05)$ superior to cuttings for $H 89 / 8, \mathrm{Cl} 86-89$ and \%BS89/8 while they were equivalent for total heights till 1988 . Level of variability of vegetatively propagated material was slightly more important than for seedlings.

Static stability (Becker and Leon, 1988) of both material origins was judged across blocks based on environmental variances (ie between blocks variances) and tested by Hartley's test for H89/8, Cl86-89, and SS89/8. Table VI indicates no significantly different ( $\alpha=0.05$ ) variances of both material for vigour traits, but highly significant ones $(\alpha=0.01)$ for stem form with higher variances for seedlings compared to cuttings, suggesting a higher static instability of seedlings for that trait.

Vegetative propagation is a valuable technique in reforestation as far as it has no or little adverse effects on the field performance of the propagules (Karlsson and Russell, 1990). Several studies have shown equivalence of rooted cutting and seedling behaviour for various species. Superiority of cuttings has even been mentioned, usually for stem form traits (Sweet and Wells, 1974; Klomp and Hong, 1985; Karlsson and Russell, 1990) and homogeneity of response.

Our results are in general agreement with this conclusion for the family F0001. Nevertheless, due to the advantage of age and to the initial selection of ortets $(P=$ $10 \%$, one might have expected cuttings to be even more superior to seedlings than observed in this study. Some restrictions also exist for the seed orchard progeny F0025, connected with possible maturation

Table V. Comparison of forest performances (means and coefficients of variation in brackets) between seedlings $(S)$ and rooted cuttings (C) (exp 1).

\begin{tabular}{|c|c|c|c|c|c|c|c|c|}
\hline Family & $\mathrm{Ni}$ & $\% S 89$ & $\begin{array}{l}H 86 / 5 \\
(\mathrm{~cm})\end{array}$ & $\begin{array}{l}H / 89 / 8 \\
(\mathrm{~cm})\end{array}$ & $\begin{array}{c}\text { C186-89 } \\
(\mathrm{cm})\end{array}$ & \%BS89/8 & SS89/8 & $\%$ CS $89 / 8$ \\
\hline F0001 S & 18 & 77.8 & $\begin{array}{c}112.6 \\
(23.5)\end{array}$ & $\begin{array}{c}379.1 \\
(11.1)\end{array}$ & $\begin{array}{r}266.5 \\
(9.8)\end{array}$ & 28.6 & $\begin{array}{r}3.57 \\
(30.5)\end{array}$ & 50.0 \\
\hline F0001 C & 123 & 91.1 & $\begin{array}{c}107.4 \\
(26.3)\end{array}$ & $\begin{array}{l}366.0 \\
(16.6)\end{array}$ & $\begin{array}{c}258.6 \\
(16.2)\end{array}$ & 33.6 & $\begin{array}{r}3.25 \\
(31.7)\end{array}$ & 57.0 \\
\hline TEST $1 / t$ & & NS & NS & NS & NS & NS & NS & NS \\
\hline F0025 S & 18 & 88.9 & $\begin{array}{c}115.9 \\
(30.6)\end{array}$ & $\begin{array}{c}374.1 \\
(17.1)\end{array}$ & $\begin{array}{c}258.3 \\
(12.7)\end{array}$ & 12.5 & $\begin{array}{r}3.76 \\
(27.4)\end{array}$ & 56.3 \\
\hline F0025 C & 78 & 70.5 & $\begin{array}{c}98.5 \\
(29.6)\end{array}$ & $\begin{array}{l}329.5 \\
(19.8)\end{array}$ & $\begin{array}{c}231.0 \\
(20.0)\end{array}$ & 42.3 & $\begin{array}{r}3.29 \\
(28.6)\end{array}$ & 63.5 \\
\hline Test $1 / t$ & & NS & NS & * & * & NS & NS & NS \\
\hline
\end{tabular}

* Significantly different at $\alpha=0.05$; see table III for explanation of trait symbols. 
Table VI. Mean family performances and standard deviations over blocks. Hartley's test for comparison of inter-block variances $(\exp 1)$.

\begin{tabular}{lccc}
\hline Family & H89/8 $(\mathrm{cm})$ & Cl86-89 $(\mathrm{cm})$ & $S S 89 / 8$ \\
\hline F0001S & $379.5 \pm 19.4$ & $265.3 \pm 12.8$ & $3.438 \pm 1.148$ \\
F0001 C & $366.8 \pm 14.4$ & $258.9 \pm 11.3$ & $3.295 \pm 0.227$ \\
Hartley & $1.807 \mathrm{NS}$ & $1.137 \mathrm{NS}$ & $25.576^{* *}$ \\
& & & \\
F0025 S & $374.1 \pm 45.7$ & $258.3 \pm 19.8$ & $3.375 \pm 0.835$ \\
F0025 C & $327.1 \pm 38.2$ & $230.9 \pm 28.7$ & $3.275 \pm 0.261$ \\
Hartley & $1.434 \mathrm{NS}$ & $2.111 \mathrm{NS}$ & $10.235^{* *}$ \\
\hline
\end{tabular}

NS $=$ Non significantly different at $\alpha=0.05 ;{ }^{* *}=$ significantly different at $\alpha=0.01$.

effects of cutting donor plants as suggested by Morgenstern et al (1984) and Struve and MacKeand (1990). Indeed, they were $1 \mathrm{yr}$ older than those of family F0001. Another reason suggested by data of table 1 on the quality of the root system could be that a high proportion of rooted cuttings of that family (Lkd C) would in fact be substandard. Mason (1986) also observed in several experiments set up since 1978 on hybrid larch that cutting growth is mostly indistinguishable from growth of normal stock in the best plots, discarding substandard plants.

A more thorough experiment with a larger number of families and even-aged material will be required for a precise comparison of seedlings and cuttings.

\section{CONCLUSION}

Vegetative propagation has been presented as a theoretically valuable tool for capturing most of the genetic variability in a production variety (Burdon and Shelbourne, 1974). Nevertheless, practical limitations exist connected with the technical methods of rooting and biological con- straints such as ageing of donor plants, ' $\mathrm{C}$ '-effects and efficiency of early ortet selection exist, not to mention economic viability considerations when commercial production is planned (Roulund, 1981).

Numerous papers have been published on technical aspects for rooting larches, and the hybrid larch in particular (see Jacques and Nanson, 1989 for a literature review) but few have questioned the interest of clonally propagated material up to forest development stage.

Our preliminary results up to age $8 \mathrm{yr}$ (from propagation) are optimistic as regards the use of rooted cuttings in reforestation as most important of all, cuttings behave mostly like seedlings. Moreover, fears about a probable change over time of the genetic composition of multiclonal varieties do not seem to be justified in the present study.

Nevertheless, our study stresses several problems inherent in propagation via stem cuttings:

- The great variability of clone response to rooting: several clones have an excellent, or on the contrary, a poor rooting ability. Repeated further experiments on difficult- 
to-root clones have tended to prove that this behaviour is systematic and genetically controlled. Fortunately, it concerns few clones and in order to control the composition of clonal varieties as much as possible, these should be discarded as soon as detected.

- The importance in clonal tests of taking cuttings from even-aged donor plants as ' $C$ '-effects or at least-age effects of donor plants can be very severe on rooting (Chandler, 1960; Morgenstern et al, 1984) but also on further development over a long period.

- Transfer of rooted cuttings from greenhouse conditions to nursery environment is a delicate phase which might have serious deleterious effects on the final multiplication rate.

- The present study does not allow determination of the efficiency of early ortet selection on further development of ramets, but within the range of the selection criteria chosen (total height at age $2 \mathrm{yr}$ ), no ortetramet correlations could be found between initial ortet vigour and rooting behaviour of ramets.

Besides addressing biological and technical problems, use of vegetative propagation for mass propagation of varieties will be finally supported by the prospect of high genetic (genotypic) gains through selection. These might indeed be required to compensate for the extra cost connected with the propagation technique. A study on levels of expected genotypic gains through clonal selection will be presented in a future paper.

\section{ACKNOWLEDGMENTS}

The technical assistance of $G$ Chanteloup, $J$ Coupaye and $P$ Delanzy for cutting propagation, $P$ Legroux and $M$ Faucher for data collection and C Schneider for statistical analysis is gratefully acknowledged.

\section{REFERENCES}

Arbonnier P (1966) L'analyse de l'information. Aperçu théorique et application à la loi multinomiale. Ann Sci For 23(4), 950-1017

Bastien JC, Keller R (1980) Intérêts comparés du mélèze hybride (Larix $\mathrm{x}$ eurolepis Henry) avec les deux espèces parentes. Rev For Fr 32(6), 521-530

Becker HC, Leon J (1988) Stability analysis in plant breeding. Plant Breed 101, 1-23

Burdon RD, Shelbourne CJA (1974) The use of vegetative propagules for obtaining genetic information. $N Z J$ For Sci 4, 418-425

Chandler C (1960) The propagation of Larix from softwood cuttings. Proc 7 th Northeast For Tree Improv Conf, 1953, 32-39

Dagnelie P (1975) Théorie et Méthodes Statistiques. Presses Agronomiques de Gembloux, Gembloux, vol II, 463 pp

Gothe $H$ (1987) Ein Kreuzungsversuch mit Larix europaea DC, Herkunft Schlitz, und Larix leptolepis Gord. Allg Forstztg 158(1), 1-3

Jacques D, Nanson A (1989) Essais de Bouturage du Mélèze Hybride en Belgique. Stat Rech For Hydrobiol Groenendaal, Trav Sér E No7, $51 \mathrm{pp}$

Karlsson I, Russell J (1990) Comparisons of yellow cypress trees of seedling and rooted cutting origins after 9 and 11 years in the field. Can J For Res (20), 37-42

Keiding $H$, Olsen HC (1965) Assessment of stem form in clones and progenies of larch. Silvae Genet 14(4), 115-122

Klomp BK, Hong SO (1985) Performance of Pinus radiata seedlings and cuttings to age 15 years. N Z J For Sci 15, 281-297

Mason WL (1984) Vegetative Propagation of Conifers Using Stem Cuttings. II. Hybrid Larch. For Comm, Res Inf Note 91/84/SILN, $3 \mathrm{pp}$

Mason WL (1986) Vegetative Propagation of $\mathrm{Hy}$ brid larch. Rep For Res, Edinburgh, p 16

Mason WL (1989) Vegetative propagation of hybrid larch (Larix $\mathrm{x}$ eurolepis Henry) Using winter cuttings. For Supp/62, 189-198

Morgenstern EK (1987) Methods for rooting of larch cuttings and application in clonal selection. For Chron 6, 174-178

Morgenstern EK, Nicholson JM, Park YS (1984) Clonal selection in Larix laricina. I. Effects of 
age, clone and season on rooting of cultings. Silvae Genet 33(4-5), 155-160

Pâques LE (1989) A critical review of larch hybridization and its incidence on breeding strategies. Ann Sci For 46, 141-153

Roulund $H$ (1981) Problems of clonal forestry in spruce and their influence on breeding strategy. For Abstr 42(10), 457-471
Struve DK, Mackeand SE (1990) Growth and development of eastern white pine rooted cuttings compared with seedlings through 8 years of age. Can J For 20, 365-368

Sweet GB, Wells LG (1974) Comparison of the growth of vegetative propagules and seedlings of Pinus radiata. $N Z J$ For Sci 4, 399409 